\title{
The Dynamics of Identity Negotiation in a Border Region: The Case of Georgian Azeri-Turks of Kvemo Kartli
}

\author{
Karli-Jo T. Storm \\ Jyväskylä: Grano Oy 2019 \\ 188 sidor. ISBN 9789526132511
}

Recenserad av Minna Lundgren [PhD, lektor i sociologi, Mittuniversitetet, minna. lundgren@miun.se]

I den postsovjetiska sfären är det fortsatt den etnonationella identiteten som utgör den primära grunden för nationsbyggande. I Georgien, det land i södra Kaukasus som har den mest heterogena befolkningen, utgörs mer än 13 procent av olika minoritetsgrupper. Den tu rk-azeriska ${ }^{1}$ minoriteten, vanligtvis bosatta i de sydöstra delarna av landet, är den största och omfattade vid folkräkningen 2014 över 233000 personer, eller 6,3 procent av befolkningen. Frågan är emellertid hur och på vilket sätt minoriteter bereds utrymme i dagens georgiska nationsbygge. Det är detta KarliJo T. Storm fokuserar i sin avhandling The Dynamics of Identity Negotiation in a Border Region: The Case of Georgian Azeri-Turks of Kvemo Kartli.

I avhandlingen, som består av en inledande sammanfattande kappa och fem fristående artiklar, tar Storm ett övergripande teoretiskt avstamp i klassiska arbeten om nationen och nationsbyggande genom verk av bland andra Benedict Andersson, Anthony Smith och Anssi Paasi. De fem artiklarna kan delas in i två delar, där de första två artiklarna fokuserar det georgiska nationsbyggandet och de tre efterföljande artiklarna är specifikt inriktade på hur nationsbyggandets gränsdragningar tar sig i uttryck i relation till den turk-azeriska minoriteten. I den första artikeln Unpacking the Georgian Nation: Interpreting the Symbolic Boundaries of Membership through National Iconography studerar Storm formen för den nationella identitet som representeras och reproduceras på statlig nivå i Georgien. Detta gör hon genom studier av symboliska avgränsningar av gruppmedlemskap och ikonografiska uttryck. Medan en symbolisk avgränsning av den georgiska nationen formuleras i den georgiska nationalismens fader Ilia Chavchavadzes berömda triad mamuli (fädernesland), ena

\footnotetext{
${ }^{1}$ Gruppens historia är mångfacetterad och går långt tillbaka med kopplingar till olika turkfolk som levt i området. Storm har valt att använda termen "Georgian Azeri-Turk», vilket jag utifrån vokabulärens begränsningar på svenska valt att översätta till georgiska turk-azerier.
} 
(språk) och sartsmunoeba (religion) anser Storm att detta inte är något som enbart tillhör det förflutna, utan det präglar också hur georgiskheten ikonografiskt yttras i nutid på till exempel heraldiska vapen, sedlar och i både civila och religiösa nationella helgdagar.

Georgiskhetens fysiska gestaltning är också temat för avhandlingens andra artikel Flexible Memory Narratives in the Physical Landscape: A Case Study of Tbilisi, Georgia där Storm tar sig an förändringar i huvudstadens stadsbild efter rosenrevolutionen 2003. Storm menar här att parallellt med Chavchavadzes triad om fädernesland, språk och religion präglas det kollektiva postsovjetiska minnesskapandet av tre centrala narrativ: utländsk aggression, unicitet genom antiken samt återvändande till väst, och också detta påverkar utformningen av den fysiska miljön. Det manifesteras genom bland annat minnesmonument, religiösa byggnader och gravplatser samt nya (transparenta) byggnadsverk i glas. Emellertid domineras det byggda rummet av det georgiska, medan landets minoriteter får litet utrymme.

I avhandlingens tredje artikel Whither the Vatzn? The Framing of Homeland in Official Discourse vis-à-vis Georgia's Azeri-Turk Population söker Storm svara på frågan hur och varför ledare i de postsovjetiska Georgien och Azerbajdzjan positionerat respektive territorialstat som hemland för den georgiska turk-azeriska populationen. $\AA$ ena sidan har den azerbajdxjanska regimen, under först Heidar Aliyev och sedan Ilham Aliyev, formulerat och verkat utifrån existensen av en azerbajdzjansk diaspora som ska understödjas ekonomiskt och kulturellt på plats, men inte uppmuntras att återvända till Azerbajdzjan. Storm anser här å den andra sidan att georgiska ledare har pendlat mellan en civil inkluderande nationalism och en retorik som förstärker traditionella georgiska kulturella och religiösa värden. Detta har tagit sig form bland annat $\mathrm{i}$ initiativ för ökade möjligheter för den turk-azeriska minoriteten att ta del av högre utbildning, satsningar på infrastruktur i områden där minoritetsbefolkningar framförallt är bosatta, men samtidigt har kraven på språkkunskaper för statsanställda ökat. Sammantaget handlar det alltså om åtgärder som både inkluderar och exkluderar den turk-azeriska minoriteten.

Who and Where are We? Landscapes as Mediums of Identity Negotiation for Georgia's Azeri-Turks är titeln på den fjärde artikeln där Storm fokuserar hur nationella platsanknutna narrativ påverkar eller speglar uppfattningar om kollektiva identiteter hos representanter från den georgiska turk-azeriska minoriteten i Kvemo Kartli. Storm uttrycker att medan den georgiska staten på olika sätt, genom till exempel placering av skyltar eller organisering av georgiska festivaler vid traditionellt turkazeriska högtider, söker förstärka ett metanarrativ om landskapets nationella [georgiska] identitet, så finns det en motrörelse bland turk-azerier som ser sig som en unik sociokulturell grupp som också har en stark och historisk tillhörighet till Georgien som hemland. Här utgör platser och landskapet och de sätt på vilka dessa används en viktig del i deras kollektiva identitet.

Den sista artikeln i avhandlingen $A$ People In-Between: Examining Indicators of Collective Identity among Georgian Azeri-Turks bygger på en enkätstudie genomförd i 


\section{MINNA LUNDGREN}

Kvemo Kartli där Storm undersökt indikatorer för gruppmedlemskap i relation till kollektiva identiteter. Resultaten visar att till exempel språk, religiös tillhörighet och världsbild utgör symboliska gränsdragningar som skiljer turk-azerierna från georgier och istället är något de har gemensamt med befolkningen i Azerbajdzjan. Samtidigt utgör till exempel en »kaukasisk mentalitet», vissa civila georgiska högtider, särskilda maträtter en stark platsanknytning till ett hemland beläget i Georgien och lojalitet mot den georgiska staten aspekter av en särskild georgisk turk-azerisk identitet. Storm menar att detta är ett uttryck för den georgiska turk-azeriska minoritetens belägenhet mittemellan de georgiska och azeriska nationsbyggnadsprojekten, vilket också förstärks i och med att de är bosatta i gränsområdet mellan de båda staterna.

Genom användandet av deltagande observationer, dokumentstudier, intervjuer och enkäter har Storm erhållit ett gediget empiriskt material att grunda sina slutsatser på. Det hade emellertid varit intressant att få en inblick i de överväganden som utgör en del av forskarhantverket, och som gjorts under avhandlingsarbetet, då de två första artiklarna spretar något i relation till avhandlingens syfte. Sammantaget är detta dock en avhandling som lämnar ett viktigt teoretiskt och empiriskt bidrag till forskningen om såväl de gränsdragningar och begränsningar som präglar det georgiska nationsbyggandet som den georgiska turk-azeriska minoritetens roll och position i detta nationsbyggnadsprojekt. Genomgående för de fem artiklarna är att Storm ger oss en inblick i komplexiteten i minoritetsgruppens sociala och spatiala belägenhet när de postsovjetiska staterna strävar efter att konsolidera sina nationer. Storm har ett personligt anslag i sina texter som inte går till överdrift utan fint balanserar det vetenskapliga bidraget. 